NOTE

\title{
First record of ostracods as natural intermediate hosts of Anguillicola crassus, a pathogenic swimbladder parasite of eels Anguilla spp.
}

\author{
František Moravec $^{1, *}$, Kazuya Nagasawa $^{2}{ }$, Munenori Miyakawa ${ }^{3}$ \\ ${ }^{1}$ Institute of Parasitology, Academy of Sciences of the Czech Republic, Branišovská 31, 37005 České Budějovice, \\ Czech Republic \\ ${ }^{2}$ National Research Institute of Aquaculture, Nikko Branch, Fisheries Research Agency, Chugushi, Nikko, \\ Tochigi 321-1661, Japan \\ ${ }^{3}$ Aichi Fisheries Research Institute, 97 Wakamiya, Miya-ku, Gamagori, Aichi 413-0021, Japan
}

\begin{abstract}
The ostracod Physocypria nipponica (Ostracoda: Candonidae) was found (prevalence $14.2 \%$ ) to be the only intermediate host of the nematode Anguillicola crassus (Nematoda: Anguillicolidae), a pathogenic swimbladder parasite of eels, in a greenhouse-heated culture pond at Isshiki, Aichi Prefecture, Japan. Japanese eels Anguilla japonica from the same pond were found to be infected by adult $A$. crassus (prevalence $71.8 \%$, intensity 1 to 6 ). This indicates that $A$. crassus could complete its life cycle under conditions of modern eel-culture technology where copepods were absent due to the unfavorable water quality for them, by utilizing ostracods as the intermediate host.
\end{abstract}

KEY WORDS: Ostracoda · Physocypria nipponica · Intermediate host • Parasitic nematode • Anguillicola crassus · Japanese eel · Anguilla japonica · Japan

Resale or republication not permitted without written consent of the publisher

\section{INTRODUCTION}

The nematode Anguillicola crassus (Nematoda: Anguillicolidae) is a widely distributed swimbladder parasite of eels, which was originally described from the cultured Japanese eel Anguilla japonica Temminck et Schlegel and the introduced European eel Anguilla anguilla (L.) in Japan (Kuwahara et al. 1974), and later it was also reported from both cultured and wild eels from China and Korea (see Nagasawa et al. 1994). In the 1980s, the nematode was introduced from East Asia into Europe, where it quickly spread in many countries (e.g. Peters \& Hartmann 1986, Moravec 1992), causing serious problems in eel farms and wild eel populations. This highly pathogenic parasite was later also introduced into North Africa
(Egypt, Morocco), where it infects A. anguilla (El Hilali et al. 1996, H. Koops pers. comm.), and into North America, occurring there in the American eel Anguilla rostrata (Lesueur) (Johnson et al. 1995, Barse et al. 2001). Mass mortalities of eels due to A. crassus infection have been described, for example, in Lake Balaton in Hungary (Molnár et al. 1991), Vranov and Orlík dam lakes in the Czech Republic (Baruš 1994, Moravec 1997) and in eel aquaculture farms in Taiwan (Ooi et al. 1996).

The life cycle of Anguillicola crassus was studied experimentally by many authors in both East Asia and Europe (e.g. Hirose et al. 1976, Egusa 1979, De Charleroy et al. 1987, 1990, Kim et al. 1989, Petter et al. 1989, 1990, Moravec et al. 1993). A total of 17 species of copepod (Copepoda) have been found to serve as 
experimental or natural intermediate hosts for this parasite, in the haemocoel of which the nematode third-stage larva develops within several days; this is already infective for the fish host.

The infected copepods are generally considered to be the main source of Anguillicola crassus infection for both cultured and wild eels, although different aquatic invertebrates (snails, insect larvae) and vertebrates (fishes, amphibians) may serve as paratenic hosts (e.g. Petter et al. 1989, De Charleroy et al. 1990, Moravec 1996, Moravec \& Škoríková 1998). In Japan, Hirose et al. (1976) found the copepod Eucyclops serrulatus to be a suitable experimental intermediate host of $A$. crassus, whereas Eucyclops euacanthus and Thermocyclops hyalinus were found as natural intermediate hosts in the pond of cultured American eels infected with A. crassus in Taiwan (Ooi et al. 1997) and in the irrigation canal near fish farms in Korea (prevalence $3.6 \%$, intensity 1 to 2 larvae) (Kim et al. 1989), respectively.

However, Petter et al. (1990) and Moravec \& Konecny (1994) found that the European ostracods Cypria ophthalmica and Notodromas monacha may serve, in addition to copepods, as suitable intermediate hosts of Anguillicola crassus under experimental conditions; however, no ostracods have so far been reported as natural intermediate hosts of this nematode.

\section{MATERIALS AND METHODS}

On 21 June 1995, zooplankton sampling was carried out with a hand-net in a greenhouse-heated culture pond $\left(660 \mathrm{~m}^{2}, 0.9 \mathrm{~m}\right.$ depth, water temperature 27 to $28^{\circ} \mathrm{C}$ ) at Isshiki $\left(44^{\circ} 48^{\prime} \mathrm{N}, 137^{\circ} 02^{\prime} \mathrm{E}\right)$, Aichi Prefecture, one of the most productive eel culture areas in Japan. The sample was fixed in 5\% formaldehyde solution, brought to the laboratory, and examined for the presence of Anguillicola crassus larvae. Japanese eels (48 to $54 \mathrm{~cm}$ total length) were also sampled from the same pond and examined for $A$. crassus.

\section{RESULTS AND DISCUSSION}

The zooplankton sample consisted of only 1 ostracod species, Physocypria nipponica Okubo, 1990 (Candonidae: Cyclocyprininae). A total of 33 out of $232 P$. nipponica (prevalence 14.2\%) were found to be infected by third-stage larvae of Anguillicola crassus (Fig. 1), with an intensity from 1 to 2 (mean 1.2) larvae per ostracod. Of 110 Japanese eels Anguilla japonica examined, 79 (prevalence $71.8 \%$ ) were infected with 1 to 6 (mean 1.3) A. crassus; gravid females with larvated eggs in uteri were present.
The third-stage larvae of Anguillicola crassus (10 specimens measured) from ostracods (Fig. 2) were 728 to $1012 \mu \mathrm{m}$ long and had a 32 to $36 \mu \mathrm{m}$ maximum width. The cephalic end was rounded, the mouth was provided with 2 tiny lateral sclerotized teeth; each was followed posteriorly by a sclerotized apparatus situated at the level of the anterior end of oesophagus, which appeared as bifurcate in lateral view; this apparatus was 8 to $10 \mu \mathrm{m}$ long and 12 to $16 \mu \mathrm{m}$ wide. The oesophagus was 204 to $276 \mu \mathrm{m}$ long and had a 26 to $32 \mu \mathrm{m}$ maximum width. The nerve ring and the excretory pore were 48 to 72 and 78 to $92 \mu \mathrm{m}$, respectively, from the anterior extremity. The intestine contained numerous brownish granulae. The tail was conical, 36 to $68 \mu \mathrm{m}$ long, with a small spike at the tip.

The present record of ostracods as natural intermediate hosts of Anguillicola crassus shows that this pathogenic parasite is capable of reproducing even under the conditions of modern fish culture technology, where copepods may be absent due to the bad quality of water in which, however, ostracods survive and become the principle source of $A$. crassus infection for the cultured eels.

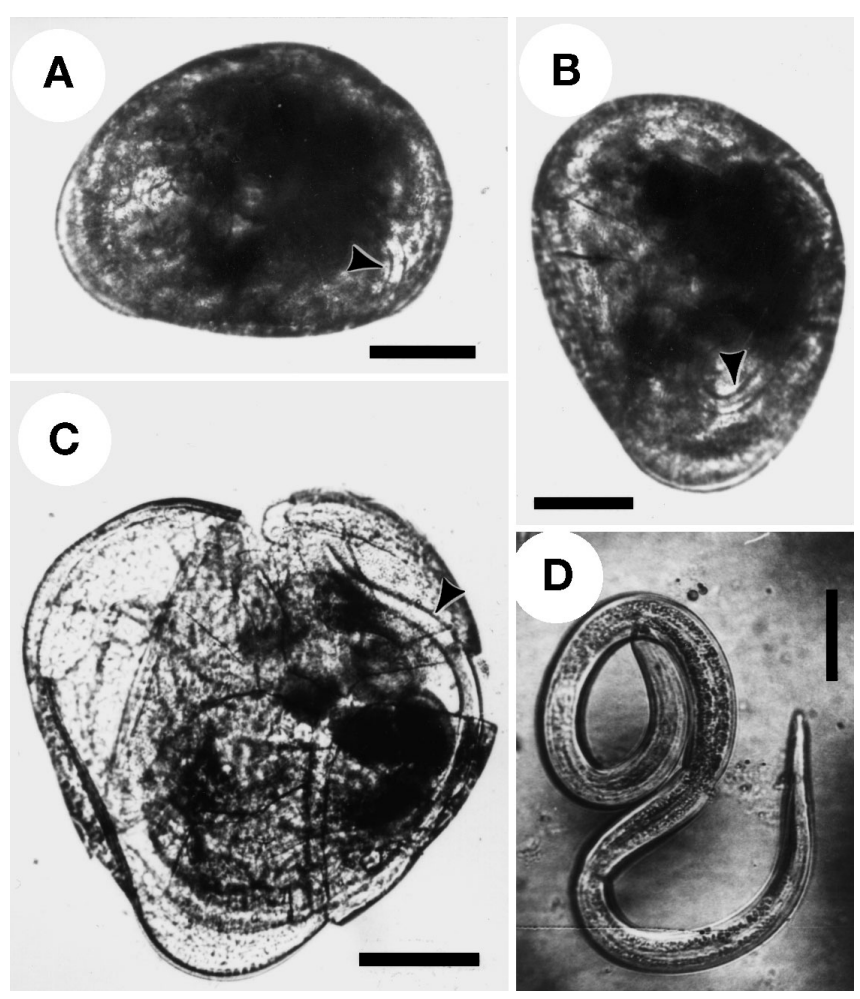

Fig. 1. Physocypria nipponica infected with Anguillicola crassus third-stage larvae. $(\mathrm{A}, \mathrm{B})$ Specimens harboring the larva (arrowheads). (C) Broken specimen containing the larva (arrowhead). (D) Larva expressed from the body of the ostracod (native). Scale bars: $A$ to $C=200 \mu m_{i} D=70 \mu \mathrm{m}$ 


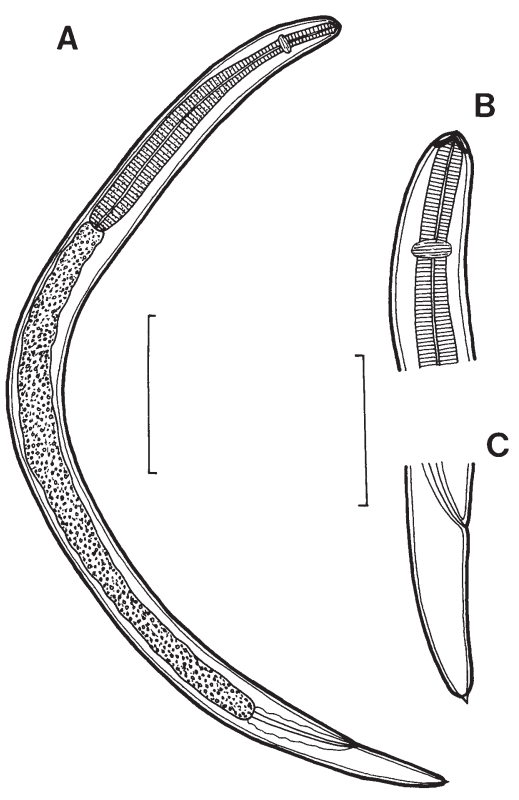

Fig. 2. Anguillicola crassus third-stage larva from the haemocoel of Physocypria nipponica. (A) General view. (B,C) Anterior and posterior ends, respectively, lateral views. Scale bars: $\mathrm{A}=100 \mu \mathrm{m} ; \mathrm{B}, \mathrm{C}=50 \mu \mathrm{m}$

Acknowledgements. The authors thank Dr. Ichiro Okubo, Shujitsu Joshi University, who kindly identified the ostracods. Thanks are also due to Mrs I. Husáková, Institute of Parasitology, Academy of Sciences of the Czech Republic (ASCR), for her help with the preparation of illustrations. This study was supported by Grant No. 524/03/0061 from the Grant Agency of the Czech Republic and the research project of the Institute of Parasitology, ASCR (No. Z60220518).

\section{LITERATURE CITED}

Barse AM, McGuire SA, Vinores MA, Eierman LE, Weeder JA (2001) The swimbladder nematode Anguillicola crassus in American eels (Anguilla rostrata) from middle and upper regions of Chesapeake Bay. J Parasitol 87:1366-1370

Baruš V (1994) Eel's life is at stake. Rybářství 11:328-329 (in Czech)

De Charleroy D, Thomas K, Belpaire C (1987) Problems concerning the species determination, biology and diagnostical methods of Anguillicola, a swim-bladder nematode in the European eel (Anguilla anguilla). In: Proc EIFAC Working Party on Eel, Eur Inland Fish Adv Commiss, Bristol, p 1-7

De Charleroy D, Grisez L, Thomas K, Belpaire C, Ollevier F (1990) The life cycle of Anguillicola crassus. Dis Aquat Org 8:77-84

Egusa S (1979) Notes on the culture of the European eel (Anguilla anguilla L.) in Japanese eel-farming ponds. Rapp PV Reun Cons Int Explor Mer 174:51-58

El Hilali M, Yahyaoui A, Sadak A, Maachi M, Taghy Z (1996) Premières données épidémiologiques sur l'anguillicolose au Maroc. Bull Fr Pêche Piscic 340:57-60

Editorial responsibility: Wolfgang Körting,

Hannover, Germany
Hirose H, Sekino T, Egusa S (1976) Notes on the egg deposition, larval migration and intermediate host of the nematode Anguillicola crassa in the swimbladder of eels. Fish Pathol 11:27-31 (in Japanese with English summary)

Johnson SK, Fries LT, Williams J, Huffman DG (1995) Presence of the parasitic swim bladder nematode, Anguillicola crassus, in Texas aquaculture. World Aquacult 26:35-36

Kim YG, Kim EB, Kim JY, Chun SK (1989) Studies on a nematode, Anguillicola crassa parasitic in the air bladder of the eel. J Fish Pathol 2:1-18 (in Korean with English abstract)

Kuwahara A, Niimi A, Itagaki H (1974) Studies on a nematode parasitic in the air bladder of the eel. I. Description of Anguillicola crassa n. sp. (Philometridea, Anguillicolidae). Jpn J Parasitol 23:275-279

Molnár K, Székely Cs, Baska F (1991) Mass mortality of eel in Lake Balaton due to Anguillicola crassus infection. Bull Eur Assoc Fish Pathol 11:211-212

Moravec F (1992) Spreading of the nematode Anguillicola crassus (Dracunculoidea) among eel populations in Europe. Folia Parasitol 39:247-248

Moravec F (1996) Aquatic invertebrates (snails) as new paratenic hosts of Anguillicola crassus (Nematoda: Dracunculoidea) and the role of paratenic hosts in the life cycle of this parasite. Dis Aquat Org 27:237-239

Moravec F (1997) Present state of research of eel anguillicolosis. Sbor 'Ochrana zdraví ryb', VÚRH JU, Vodňany, p 56-60 (in Czech with English summary)

Moravec F, Konecny R (1994) Some new data on the intermediate and paratenic hosts of the nematode Anguillicola crassus Kuwahara, Niimi et Itagaki, 1974 (Dracunculoidea), a swimbladder parasite of eels. Folia Parasitol 41: $65-70$

Moravec F, Škoríková B (1998) Amphibians and larvae of aquatic insects as new paratenic hosts of Anguillicola crassus (Nematoda: Dracunculoidea), a swimbladder parasite of eels. Dis Aquat Org 34:217-222

Moravec F, Di Cave D, Orecchia P, Paggi L (1993) Studies on the development of Anguillicola crassus Kuwahara, Niimi et Itagaki, 1974 (Nematoda: Dracunculoidea) in the intermediate host. Folia Parasitol 40:39-48

Nagasawa K, Kim YG, Hirose H (1994) Anguillicola crassus and A. globiceps (Nematoda: Dracunculoidea) parasitic in the swimbladder of eels (Anguilla japonica and $A$. anguilla) in East Asia: a review. Folia Parasitol 41:127-137

Ooi HK, Wang WS, Chang HY, Wu CH, Lin CC, Hsieh MT (1996) An epizootic of anguillicolosis in cultured American eels in Taiwan. J Aquat Anim Health 8:163-166

Ooi HK, Lin CC, Chen MC, Wang WS (1997) Eucyclops euacanthus (Copepoda: Cyclopidae) is an intermediate host of Anguillicola crassus (Nematoda: Dracunculoidea) in Taiwan. Taiwan J Vet Med Anim Husb 67:135-138

Peters G, Hartmann F (1986) Anguillicola, a parasitic nematode of the swim bladder spreading among eel populations in Europe. Dis Aquat Org 1:229-230

Petter AJ, Fontaine YA, Le Belle N (1989) Étude du dévelopment larvaire de Anguillicola crassus (Dracunculoidea) chez un Cyclopidae de la région parisienne. Ann Parasitol Hum Comp 64:347-355

Petter AJ, Cassone J, Le Belle N (1990) Observations sur la biologie des premiers stades larvaires d'Anguillicola crassus, nématode parasite d'anguille. Ann Parasitol Hum Comp 65:28-31

Submitted: February 16, 2005; Accepted: May 31, 2005 Proofs received from author(s): August 23, 2005 